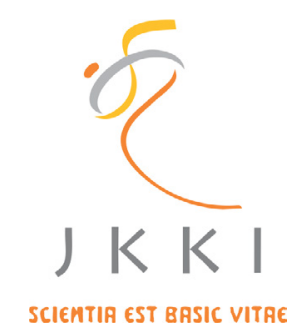

Jurnal Kedokteran dan Kesehatan Indonesia

Indonesian Journal of Medicine and Health

Journal homepage : www.journal.uii.ac.id/index.php/JKKI

\title{
Comparison of meloxicam, tamsulosin and combination of both drugs with 16 Fr and 20 Fr catheter on trial without catheter successfulness in patients with benign prostatic hyperplasia
}

\author{
Hasroni Fathurrahman ${ }^{1}$,Doddy Moesbadianto Soebadi*1 \\ ${ }^{1}$ Department of Urology, Faculty of Medicine, Universitas Airlangga, Surabaya, Indonesia
}

Original Article

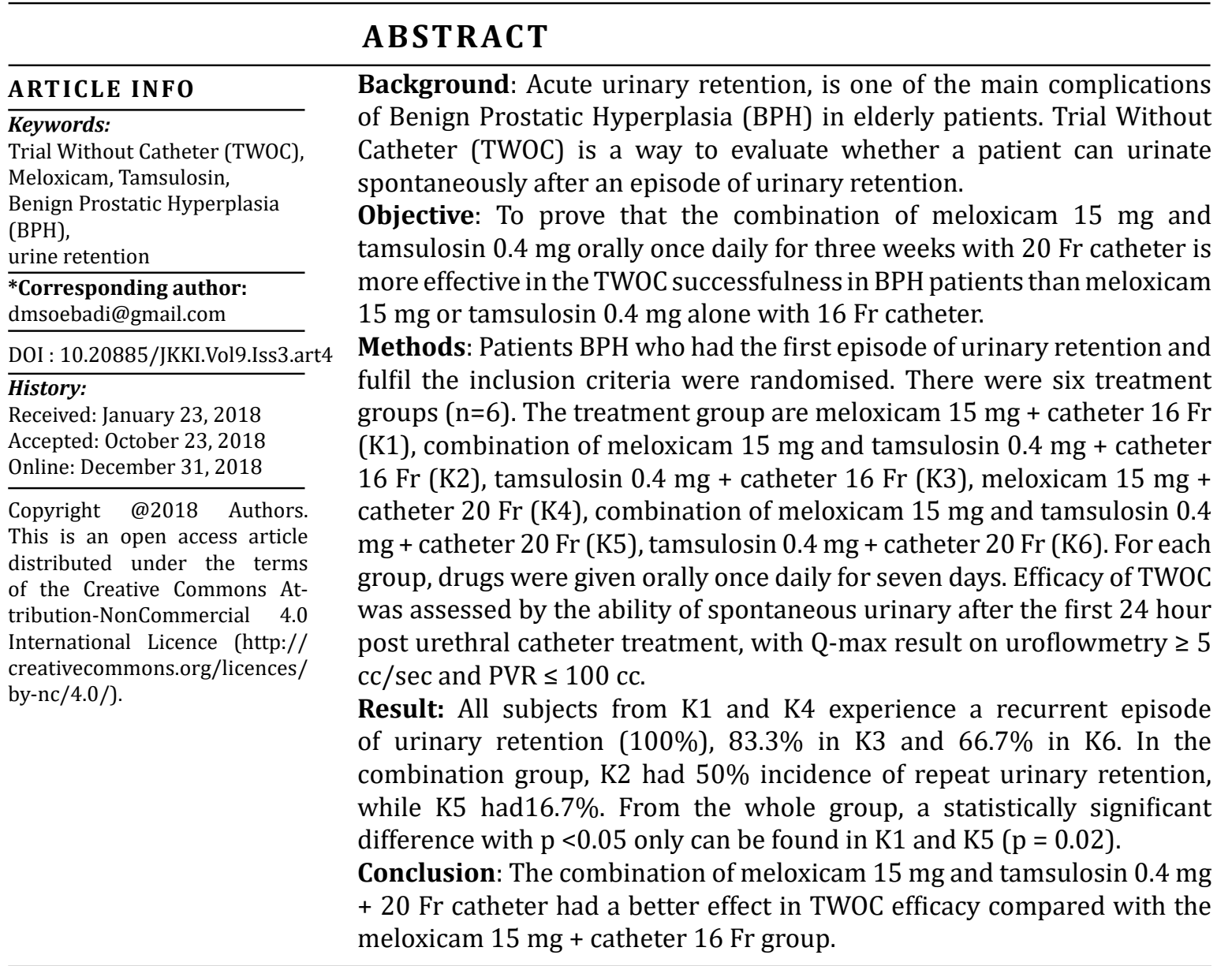

Latar Belakang: Retensi urin akut ( Acute Urinary Retention; AUR), merupakan salah satu komplikasi utama Benigna Prostat Hiperplasia (BPH) pada pasien usia lanjut. Trial Without Catheter (TWOC) adalah cara untuk mengevaluasi apakah pasien dapat berkemih secara spontan setelah terjadi retensi urin.

Tujuan: Membuktikan bahwa pemberian kombinasi meloxicam $15 \mathrm{mg}$ dan tamsulosin $0.4 \mathrm{mg}$ per oral sekali sehari selama 3 minggu lebih efektif dalam keberhasilan TWOC terhadap pasien BPH yang dipasang kateter $16 \mathrm{Fr}$ dan $20 \mathrm{Fr}$ dibandingkan dengan pemberian tamsulosin $0.4 \mathrm{mg}$ saja atau meloxicam $15 \mathrm{mg}$ saja.

Metode: Pasien BPH yang mengalami episode pertama retensi urin yang memenuhi kriteria inklusi dilakukan randomisasi sehingga terdapat 6 kelompok perlakuan, $n=6$ untuk masing-masing kelompok. 
Kelompok perlakuan tersebut antara lain: meloxicam $15 \mathrm{mg}+$ kateter $16 \mathrm{Fr}$ (K1), kombinasi meloxicam $15 \mathrm{mg}$ dan tamsulosin $0.4 \mathrm{mg}+$ kateter $16 \mathrm{Fr}(\mathrm{K2})$, tamsulosin $0.4 \mathrm{mg}+$ kateter $16 \mathrm{Fr}(\mathrm{K} 3)$, meloxicam $15 \mathrm{mg}+$ kateter $20 \mathrm{Fr}$ (K4), kombinasi meloxicam $15 \mathrm{mg}$ dan tamsulosin $0.4 \mathrm{mg}+$ kateter $20 \mathrm{Fr}$ (K5), tamsulosin $0.4 \mathrm{mg}+$ kateter $20 \mathrm{Fr}$ (K6). Untuk masing-masing kelompok obat diberikan per oral sekali sehari selama 7 hari. Dinilai keberhasilan TWOC yaitu kemampuan berkemih secara spontan setelah diberikan perlakuan 24 jam pertama paska pelepasan kateter uretra, dengan hasil Qmax pada uroflowmetri $\geq 5 \mathrm{cc} /$ detik dan Post Void Residual $(P V R) \leq 100$ cc.

Hasil: Hasil penelitian menunjukkan semua subyek dari K1 dan K4 100\% insidensi retensi urin ulang. K3 sebesar 83.3\%, dan K6 sebesar 66.7\%. Kelompok kombinasi, K2 mengalami insidensi retensi urin ulang sebanyak 50\% sedangkan kelompok kombinasi K5 sebanyak 16.7\%. Dari keseluruhan kelompok, didapatkan bahwa hanya pada K1 dan $K 5$ didapatkan perbedaan yang bermakna secara statistik dengan nilai $p<0.05(p=0.02)$.

Kesimpulan: Kombinasi meloxicam $15 \mathrm{mg}$ dan tamsulosin $0.4 \mathrm{mg}$ dengan penggunaan kateter 20 Fr memiliki efekyang lebih baik dalam keberhasilan TWOC pada pasien BPH jika dibandingkan dengan kelompok kateter $16 \mathrm{Fr}+$ meloxicam $15 \mathrm{mg}$.

\section{INTRODUCTION}

Prevalence of benign prostatic hyperplasia $(\mathrm{BPH})$ is 253 in each 1000 population. In the 60-69 year age group, the prevalence increases to 430 in each 1000 male population. ${ }^{1}$ Above 50 years, the incidence of BPH increased by $10 \%$ for each decade and reached $80 \%$ in men in the 80 's. ${ }^{2}$ Histologic, and clinical criteria for BPH were used as a basis for calculating prevalence and incidence. ${ }^{3}$ In Indonesia, no accurate data describes the prevalence or incidence of $\mathrm{BPH}$. From 1994 until 2013, about 3.804 cases of BPH were found at Cipto Mangunkusumo Hospital (RSCM) with an average age are 66.61 years old. ${ }^{4}$

Stromal cell and the prostate epithelium hyperplasia in the periurethral area, commonly occur and can be seen in the fetal developmental process. This process is the basis for the embryonic concept reawakening in $\mathrm{BPH}$. However, biomolecular aetiology underlying $\mathrm{BPH}$ is still unclear. Androgens, estrogens, stromal-epithelial interactions, growth factors and neurotransmitters, either independently or dependently can play a role as the aetiology of prostate hyperplasia. Further research has shown that the increased size of prostate is due to an increase in stromal and epithelial cells proliferation and also the disruption of apoptotic prostate cells. ${ }^{3}$

Prostate inflammation implies the aetiology and pathogenesis of BPH through static factor (prostate enlargement) and dynamic factor (smooth muscle contraction). Chronic inflammation is strongly associated with the degree of severity and accelerated deterioration of lower urinary tract syndrome (LUTS). Destruction of stromal and glandular prostate elements by proinflammatory cells causes tissue damage and ultimately results in prostate volume enlargement. Compared with non-inflammatory prostate tissue, BPH patients accompanied by prostate inflammation exhibit greater prostate volume, more severe LUTS symptoms and a higher tendency for urinary retention. ${ }^{5,6}$

Acute urinary retention (AUR) defined as a sudden inability to involuntary urination. About $10 \%$ AUR is' 80 s, and $33 \%$ AUR is ' 89 s. ${ }^{7}$ In male, AUR can be caused by BPH. In the United States and the United Kingdom, transurethral resection of the prostate (TURP) procedure is applied in $20-42 \%$ of BPH patients with AUR complications. ${ }^{8}$ The incidence of AUR in men is $0.4-25 \%$ each year. ${ }^{9}$ Other study said that $44 \%$ of patients with BPH have an acute urinary retention. ${ }^{10}$

Acute urinary retention can be caused by a sudden stimulation of $\alpha$-adrenergic receptor. This possibly as a result of an infarction in prostate tissue. This condition will increase smooth muscle tonus in prostate and capsule, so the bladder outlet resistance rises. The dominance of sympathetic nervous activity will also increase smooth muscle tonus at the bladder neck and posterior urethra. ${ }^{10}$

Trial without catheter (TWOC) is a way to evaluate whether patients can urinate spontaneously after urinary retention. After the catheter is released, the patient is required to 
perform urine flow (uroflowmetry) by inspection and the measurement of residual urine (residual microscopic volume). Trial without catheter can only be conducted after administration of $\alpha 1$-blockers (for a minimum of 3-7 days), in patients with the first episode of acute urinary retention and has not yet established a definitive diagnosis. ${ }^{3,10}$ Tamsulosin, is an $\alpha 1$ a adrenergic receptor antagonist. It is used to treat symptomatic BPH, chronic prostatitis, help the passage of kidney stones and for urinary retention. Tamsulosin and other medications in alpha blockers class works by relaxing bladder neck and muscle fibres in prostate and making it easier to urinate. ${ }^{11-13}$ Thus, increasing the success of TWOC. $8,13,14$

Acute urinary retention can also cause by inflammation process. Mild to severe inflammation can be found in 55\% of $\mathrm{BPH}$ patients with AUR. ${ }^{15}$ Cyclooxygenase (COX) is a major enzyme in the conversion of arachidonic acid into prostaglandins on the inflammatory process. One of the COX enzyme isoforms is COX2. Cyclooxygenase will induce prostaglandins and increased expression of Bcl-2. Prostaglandins will lead to an increased growth of prostate smooth muscle cells, and Bcl-2 will inhibit cells apoptosis in prostate tissue. As a result, the prostate will enlarge. ${ }^{16}$

Administration of COX-2 inhibitors can reduce and even stop the inflammatory processes occurring in BPH. Several COX-2 inhibitors such as celecoxib, tenoxicam and meloxicam have been used as the treatment of BPH. Oral celecoxib 10 milligrams (mg) once daily for one month are sufficient for the refractory nocturia complaints. ${ }^{17}$ Combination of tenoxicam 20 $\mathrm{mg}$ and alpha-blocker increase international prostate symptom score (IPSS), IPSS-quality of life (IPSS-QoL) and overactive bladder symptom score (OABSS) in LUTS patients caused by BPH compared to control group (receiving alphablockers only).$^{18}$ Combination of oral meloxicam $15 \mathrm{mg}$ and doxazosin $4 \mathrm{mg}$ once daily for six weeks increase the maximum urine flow rate (Qmax) and decrease prostate blood flow in BPH patients with LUTS. ${ }^{19}$ A systematic review and meta-analysis of non steroid anti-inflammation drugs (NSAID) effect by Kahokehr et al. (2013) concluded that there were improvements in LUTS and urinary emissions as a result of NSAID administration. No serious adverse effects on NSAID administration is shown. ${ }^{20}$

The TWOC procedure as management of AUR in BPH patients is applied to more than 79\% cases in France, Asia, Latin America, Algeria, and middle east countries. Success rate of TWOC after alpha-blocker treatment in all age groups of BPH with AUR reached $63.4 \%{ }^{10}$ Success rate of TWOC after tamsulosin $0.4 \mathrm{mg}$ compared with placebo was $63 \%$ and $37 \%$, respectively. Although the success of TWOC as the primary end-point between the tamsulosin group and the placebo group was not statistically significant, re-catheterisation in tamsulosin group proved to be lower and statistically significant compared with the placebo group. ${ }^{11,12}$

Until now, rarely or even no studies have used meloxicam or other COX-2 preparations for TWOC procedures. Therefore, a research should be performed to proves whether meloxicam alone or combination (meloxicam and tamsulosin) is more effective than tamsulosin alone in TWOC $\mathrm{BPH}$ patients who experienced the first episode of urinary retention.

\section{METHODS}

The study was designed in randomised posttest-controlled group.Subjects were randomized to 6 treatment groups. There are three doses of drugs (D) for this research. D1: meloxicam $15 \mathrm{mg}$, D2: meloxicam $15 \mathrm{mg}$ + tamsulosin $0.4 \mathrm{mg}$ while D3: only using tamsulosin $0.4 \mathrm{mg}$. The catheter that was used in this research is 2 size (16F dan 20F).

The treatment group included:

K1: meloxicam $15 \mathrm{mg}$ + catheter $16 \mathrm{Fr}$

K2: combination of meloxicam $15 \mathrm{mg}$ and tamsulosin $0.4 \mathrm{mg}$ + catheter $16 \mathrm{Fr}$

K3: tamsulosin $0.4 \mathrm{mg}+$ catheter $16 \mathrm{Fr}$ K4: meloxicam $15 \mathrm{mg}+$ catheter $20 \mathrm{Fr}$

K5: combination of meloxicam $15 \mathrm{mg}$ and tamsulosin $0.4 \mathrm{mg}$ + catheter $20 \mathrm{Fr}$

K6: tamsulosin $0.4 \mathrm{mg}$ + catheter $20 \mathrm{Fr}$ 


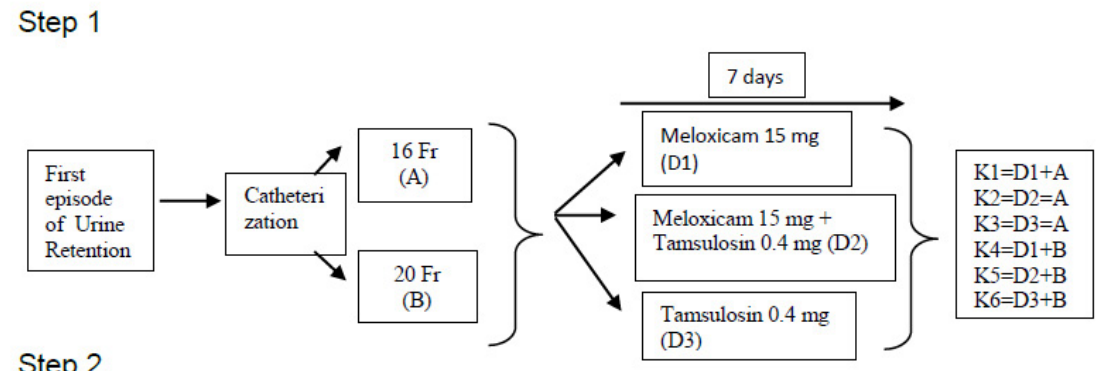

Step 2

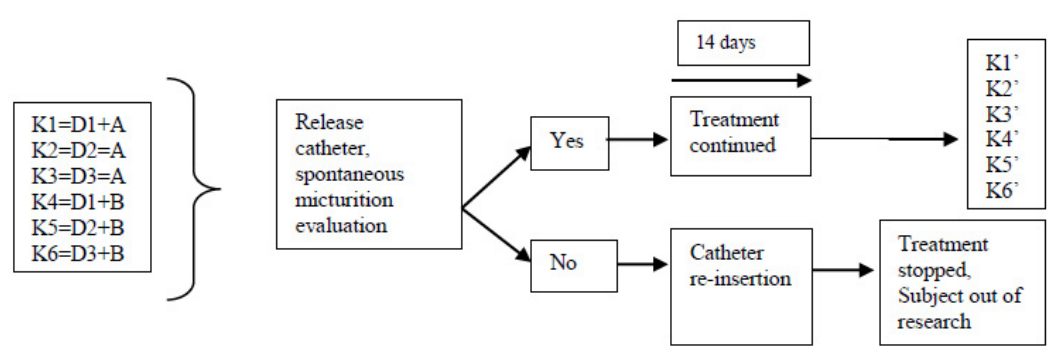

Figure 1. Flow Research Post-test evaluation:

$\mathrm{K} 1, \mathrm{~K} 2, \mathrm{~K} 3, \mathrm{~K} 4, \mathrm{~K} 5, \mathrm{~K} 6 \rightarrow$ spontaneous micturition, IPSS, Qmax, PVR

$\mathrm{K} 1$ ', K2', K3 ', K4', K5 ', K6' $\rightarrow$ Monitoring of drug side effects

After the treatment, urethral catheter was removed. Recurrent urine retention within 24 hours after the release of the catheter was clinically assessed. In case of retention, a recatheterisations classified as a failed group. The successful group defined as a spontaneous micturition sample, IPSS scoreless than or equal to 7, maximum urinary emission (Q-max) were more than $5 \mathrm{cc} / \mathrm{sec}$ on uroflowmetric examination (2nd and 3rd weeks posttreatment), with residual urine (PVR) less than $100 \mathrm{cc}$ measured by transabdominal sonography. Three weeks medication for each post-treatment group was given and observed for the side effects of drugs.

\section{Subject}

The study population was the patient who experienced first urine retention due to prostate enlargement at regional general hospital Dr Soetomo and RS Airlangga University Surabaya.

The inclusion criteria of this study are:

- Urinary retention patient with prostate enlargement confirmed by rectal examination

- Age more than 50 years

- No abnormality on kidney and liver function

- Willing to fill in and sign a statement form of willingness to follow the research.
And the exclusion criteria are:

- Allergy to non-steroid anti-inflammatory drugs (NSAIDs)

- History of gastritis, based on anamnesis (pain or burning sensation in epigastrium, nausea, vomiting, and bloating)

- Impaired liver function (elevated serum transaminase levels)

- History of alpha-blocker or COX-2 inhibitor therapy in the last two weeks

- History of consumption drugs that trigger urinary retention such as decongestant or anti-influenza in the last two weeks

- History of diabetes mellitus diagnosed over the past year and uncontrolled

- History undergoes surgery on the prostate (open or endoscopic)

- Proven to suffer from prostate carcinoma based on biopsy results of ten cores

- Subject ho refused to continue the administration of drugs/treatment,

- Subject who had a mild repetitive adverse effect and the severe side effect

\section{DATA ANALYSIS}

The relationships between variables were analysed by One-way ANOVA, Mann-Whitney test, Kruskal-Wallis test, Tamhanne and Fisher 
test with 95\% confidence level using SPSS RESULTS

software support.

Patient Characteristics

Table 1. Characteristics patient of TWOC

\begin{tabular}{lcccccc}
\hline Characteristic & K1 & K2 & K3 & K4 & K5 & K6 \\
\hline Age (year)\# & $69.00 \pm 5.40$ & $57.67 \pm 4.76$ & $65.00 \pm 9.38$ & $66.33 \pm 3.78$ & $70.50 \pm 12.11$ & $67.00 \pm 5.90$ \\
Q-max Post & 1.05 & 5.90 & 4.35 & 1.75 & 8.8 & 4.35 \\
TWOC (ml/s) & $(0-4.4)$ & $(0-10.8)$ & $(0-8.0)$ & $(0-4.8)$ & $(0-10.8)$ & $(0-10.1)$ \\
\#\# & & & & & & \\
$\begin{array}{l}\text { Post Voiding } \\
\text { Residual (PVR) }\end{array}$ & $163.43 \pm$ & $93.28 \pm$ & $74.65 \pm$ & $190.00 \pm$ & $52.78 \pm 26.70$ & $144.0 \pm$ \\
\# & 40.17 & 58.82 & 72.67 & 17.89 & & 79.68 \\
$\begin{array}{l}\text { Void Volume } \\
\text { (Vvol) \#\# }\end{array}$ & $28(0-128)$ & $99(0-130)$ & $68.55(0-$ & $45.17(0-$ & $161.50(38-$ & $70.5(0-191)$ \\
$\begin{array}{l}\text { Intravesical } \\
\text { protrusion of } \\
\text { prostate IPP } \\
\text { (cm) }\end{array}$ & $0.5 \pm(0.11)$ & $0.45 \pm 0.12$ & $0.40 \pm 0.06$ & $0.28 \pm 0.08$ & $0.40 \pm 0.08$ & $0.50 \pm 0.19$ \\
\# Data is presented in mean \pm SD & & & & & \\
\#\# Data is presented in median (minimum value - maximum) & & & \\
\end{tabular}

Urine emission (Q-max) in post TWOC patients

Based on statistical data analysis, data were not normally distributed, and the variant data were not homogenous $(\mathrm{p}<0.05)$. Therefore, a Kruskal-Wallis test were performed. Based on the data analysis there was a significant difference between groups in Q-max parameter (Table 2).

Table 2. Comparison of effectiveness of therapy in each group (Q-max parameter)

\begin{tabular}{ccccc}
\hline Groups & N & Median & Min - Max & P \\
\hline K1 & 6 & 1.05 & $0-4.4$ & $0.01^{*}$ \\
K2 & 6 & 5.90 & $0-10.8$ & \\
K3 & 6 & 4.35 & $0-8.0$ & \\
K4 & 6 & 1.75 & $0-4.8$ & \\
K5 & 6 & 8.8 & $0-10.8$ & \\
K6 & 6 & 4.35 & $0-10.1$ & \\
${ }^{*} \mathrm{p}<0.05$ & & & &
\end{tabular}

Based on the results, there is a significant difference in each group. A MannWhitney test (Post hoc test) were performed to determine the differences between groups. Based on the MannWhitney test there were statistically significant difference of statistical Q value between K5-K4 and K1-K5 (Table 3).

\section{Post voiding residual (PVR) in post TWOC patients}

Data were normally distributed ( $p>0.05)$. Therefore, one-way ANOVAtest was used. There were a significantly differences of in each group (Table 4). 
Table 3. Post-Hoc Analysis Mann-Whitney U Comparison of Qmax between groups

\begin{tabular}{ccccccc}
\hline $\begin{array}{c}\text { Comparasion } \\
\text { between Groups }\end{array}$ & $\mathbf{n}$ & $\begin{array}{c}\text { Median } \\
\text { (Min-Max) }\end{array}$ & VS & $\mathbf{n}$ & $\begin{array}{c}\text { Median } \\
\text { (Min-Max) }\end{array}$ & P \\
\hline K1 Vs K2 & 6 & $1,05(0-4,4)$ & VS & 6 & $5,90(0-10,8)$ & 0,08 \\
K1 Vs K3 & 6 & $1,05(0-4,4)$ & VS & 6 & $4,35(0-8,0)$ & 0,06 \\
K1 Vs K4 & 6 & $1,05(0-4,4)$ & VS & 6 & $1,75(0-4,8)$ & 0,67 \\
K1 Vs K5 & 6 & $1,05(0-4,4)$ & VS & 6 & $8,8(0-10,8)$ & $0,00^{*}$ \\
K1 Vs K6 & 6 & $1,05(0-4,4)$ & VS & 6 & $4,35(0-10,1)$ & 0,09 \\
K2 Vs K3 & 6 & $5,90(0-10,8)$ & VS & 6 & $4,35(0-8,0)$ & 0,59 \\
K2 Vs K4 & 6 & $5,90(0-10,8)$ & VS & 6 & $1,75(0-4,8)$ & 0,12 \\
K2 Vs K5 & 6 & $5,90(0-10,8)$ & VS & 6 & $8,8(0-10,8)$ & 0,15 \\
K2 Vs K6 & 6 & $5,90(0-10,8)$ & VS & 6 & $4,35(0-10,1)$ & 0,75 \\
K3 Vs K4 & 6 & $4,35(0-8,0)$ & VS & 6 & $1,75(0-4,8)$ & 0,14 \\
K3 Vs K5 & 6 & $4,35(0-8,0)$ & VS & 6 & $8,8(0-10,8)$ & 0,02 \\
K3 Vs K6 & 6 & $4,35(0-8,0)$ & VS & 6 & $4,35(0-10,1)$ & 0,81 \\
K4 Vs K5 & 6 & $1,75(0-4,8)$ & VS & 6 & $8,8(0-10,8)$ & $0,00^{*}$ \\
K4 Vs K6 & 6 & $1,75(0-4,8)$ & VS & 6 & $4,35(0-10,1)$ & 0,17 \\
K5 Vs K6 & 6 & $8,8(0-10,8)$ & VS & 6 & $4,35(0-10,1)$ & 0,07 \\
\hline *0 $<05$ & & & & & &
\end{tabular}

Table 4. Comparison of effectiveness of each therapy group (PVR parameter)

\begin{tabular}{cccc}
\hline Groups & N & Mean \pm SD & P \\
\hline K1 & 6 & $163.43 \pm 40.17$ & $0.00^{*}$ \\
K2 & 6 & $93.28 \pm 58.82$ & \\
K3 & 6 & $74.65 \pm 72.67$ & \\
K4 & 6 & $190.00 \pm 17.89$ & \\
K5 & 6 & $52.78 \pm 26.70$ & \\
K6 & 6 & $144.0 \pm 79.68$ & \\
${ }^{*} \mathrm{p}<0.05$ & & &
\end{tabular}

Based on thehomogeneity test of variance, data variant was not homogeneous. Therefore, Tamhanne Post hoc test was performed. Based on it, a significant difference in PVR parameter can be found in $\mathrm{K} 1$ compared with K5 group. Similarly, K4 group compared with K5 showed p-value $<0.05$ (Table 5).

\section{Voiding volume (VVol) in patient post} TWOC.

Data were not normally distributed and the variant data were not homogenous $(\mathrm{p}<0.05)$. Therefore, data were analysed by Kruskal-Wallis test. Based on this test, no significant difference of VVol value in each group (Table 6). 
Table 5. Tamhanne's post hoc analysis of PVR comparisons between groups

\begin{tabular}{ccccc}
\hline Comparasion & Mean & \multicolumn{2}{c}{ IK 95\% } & P \\
\cline { 3 - 4 } Groupen & Difference & Minimum & Maximum & \\
\hline K1 Vs K2 & 65.15 & $1,05(0-4,4)$ & $5,90(0-10,8)$ & 0.55 \\
K1 Vs K3 & 88.78 & $1,05(0-4,4)$ & $4,35(0-8,0)$ & 0.38 \\
K1 Vs K4 & -26.57 & $1,05(0-4,4)$ & $1,75(0-4,8)$ & 0.95 \\
K1 Vs K5 & 110.65 & $1,05(0-4,4)$ & $8,8(0-10,8)$ & $0,00^{*}$ \\
K1 Vs K6 & 19.43 & $1,05(0-4,4)$ & $4,35(0-10,1)$ & 1.00 \\
K2 Vs K3 & 23.63 & $5,90(0-10,8)$ & $4,35(0-8,0)$ & 1.00 \\
K2 Vs K4 & -91.72 & $5,90(0-10,8)$ & $1,75(0-4,8)$ & 0.15 \\
K2 Vs K5 & 45.50 & $5,90(0-10,8)$ & $8,8(0-10,8)$ & 0.87 \\
K2 Vs K6 & -45.72 & $5,90(0-10,8)$ & $4,35(0-10,1)$ & 0.99 \\
K3 Vs K4 & -115.35 & $4,35(0-8,0)$ & $1,75(0-4,8)$ & 0.15 \\
K3 Vs K5 & 21.87 & $4,35(0-8,0)$ & $8,8(0-10,8)$ & 1.00 \\
K3 Vs K6 & -69.35 & $4,35(0-8,0)$ & $4,35(0-10,1)$ & 0.91 \\
K4 Vs K5 & 137.22 & $1,75(0-4,8)$ & $8,8(0-10,8)$ & $0,00^{*}$ \\
K4 Vs K6 & 46.00 & $1,75(0-4,8)$ & $4,35(0-10,1)$ & 0.98 \\
K5 Vs K6 & 91.22 & $8,8(0-10,8)$ & $4,35(0-10,1)$ & 0.43 \\
\hline${ }^{p}<0.05$ & & & &
\end{tabular}

Table 6. Comparison of effectiveness of each therapy group (Vvol parameter)

\begin{tabular}{ccccc}
\hline Groups & N & Median & Min - Max & P \\
\hline K1 & 6 & 28 & $0-128$ & 0.09 \\
K2 & 6 & 99 & $0-130$ & \\
K3 & 6 & 68.55 & $0-178$ & \\
K4 & 6 & 45.17 & $0-110$ & \\
K5 & 6 & 161.50 & $38-198$ & \\
K6 & 6 & 70.5 & $0-191$ & \\
\hline
\end{tabular}

Comparison of effectiveness between treatments to trial without catheter (TWOC) Success in patients with urinary retention

Based on Fisher test, no significant difference of TWOC success rate between K1-K2,K3-K4 and K5-K6 in 16 Fr catheter therapy group for TWOC (Table 7).

The statistically significant differences are only found on $\mathrm{K} 1$ compared with $\mathrm{K} 2$ with $\mathrm{p}$ value $<0.05$. (Table 8).
This study compared the differences between groups above. Based on the Fisher test, a statistically significant difference can be found in group $\mathrm{K} 1$ and group $\mathrm{K} 5$ ( $\mathrm{p}$ value $<0.05$ ). The use of catheter $20 \mathrm{Fr}+$ combination meloxicam $15 \mathrm{mg}$ and tamsulosin 0,4 mg (K5) had a better effect compared with catheter group $16 \mathrm{Fr}+$ meloxicam $15 \mathrm{mg}$ (K1) (Table 9). 
Table 7. Comparison of TWOC's success in the 16 Fr catheter therapy group for Trial without Catheter (TWOC) success in patients with urinary retention

\begin{tabular}{|c|c|c|c|c|c|}
\hline \multirow{3}{*}{ Groups } & \multicolumn{4}{|c|}{ TWOC } & \multirow{3}{*}{$\begin{array}{c}\mathbf{P} \\
\text { Value }\end{array}$} \\
\hline & \multicolumn{2}{|c|}{ Successful } & \multicolumn{2}{|c|}{ Unsuccessful } & \\
\hline & $\mathbf{N}$ & $\%$ & $\mathbf{N}$ & $\%$ & \\
\hline $\mathrm{K} 1$ & 0 & 0 & 6 & 100 & 0.18 \\
\hline $\mathrm{K} 2$ & 3 & 50 & 3 & 50 & \\
\hline K3 & 0 & 0 & 6 & 100 & 1.00 \\
\hline K4 & 1 & 16.7 & 5 & 83.3 & \\
\hline K5 & 3 & 50 & 3 & 50 & 0.54 \\
\hline K6 & 1 & 16.7 & 5 & 83.3 & \\
\hline
\end{tabular}

Table 8. Comparison of TWOC's success in the 20 Fr catheter therapy group on Trial without Catheter (TWOC) success in patients with urinary retention

\begin{tabular}{|c|c|c|c|c|c|}
\hline \multirow{3}{*}{ Groups } & \multicolumn{4}{|c|}{ TWOC } & \multirow{3}{*}{$\begin{array}{c}\mathbf{P} \\
\text { Value }\end{array}$} \\
\hline & \multicolumn{2}{|c|}{ Successful } & \multicolumn{2}{|c|}{ Unsuccessful } & \\
\hline & $\mathbf{N}$ & $\%$ & $\mathbf{N}$ & $\%$ & \\
\hline K1 & 0 & 0 & 6 & 100 & $0.02^{*}$ \\
\hline K2 & 5 & 83.3 & 1 & 16.7 & \\
\hline K3 & 0 & 0 & 6 & 100 & 0.45 \\
\hline K4 & 2 & 33.3 & 4 & 66.7 & \\
\hline K5 & 5 & 83.3 & 1 & 16.7 & 0.24 \\
\hline K6 & 2 & 33.3 & 4 & 66,7 & \\
\hline
\end{tabular}

\section{Side effects of drugs treatment}

Table 10 reveal that side effects of drugs such as dyspepsia were more common in the $15 \mathrm{mg}$ of meloxicam alone than in the combination group of meloxicam $15 \mathrm{mg}$ and tamsulosin $0.4 \mathrm{mg}$. No dyspepsia was found in the tamsulosin group 0.4 $\mathrm{mg}$. Symptoms of dizziness and dyspepsia more often appeared in the combination of meloxicam $15 \mathrm{mg}$ and tamsulosin, compared with $0.4 \mathrm{mg}$ tamsulosin alone. No symptoms of dizziness in the group of $15 \mathrm{mg}$ meloxicam only.

\section{DISCUSSION}

Acute urinary retention is an important issue that often occurs in elderly and causes morbidity. Acute urinary retention is one of BPH complication. One in 10 men in the seventh decade suffering from acute urinary retention. This risk will be increased three times in the eighth decade. The first action performed on an incident of acute urinary retention is by performing the catheterisation. This action can reduce decompression of the bladder and subsequent operative action. However, immediate operative action has a higher rate of complications of morbidity and mortality compared to elective surgery. ${ }^{10}$

Alpha blockers treatment cause a greater TWOC success rate in acute urinary retention patients with BPH without surgery after catheter release. The use of alfuzosin $10 \mathrm{mg}$ once daily may have greater TWOC success rate (61.9\%) than with a placebo of only $(47.9 \%)$ for six months of therapy. Alpha-1-blockers effective for LUTS management and acute urinary retention with a decreased sympathetic tone, reduced bladder outlet resistance and PVR. ${ }^{21}$ 
Table 9. Comparison of effectiveness of catheter therapy group $16 \mathrm{Fr}$ with catheter 20 Fr on trial without catheter (TWOC) success in urine retention patients

\begin{tabular}{|c|c|c|c|c|c|}
\hline \multirow{3}{*}{ Groups } & \multicolumn{4}{|c|}{ TWOC } & \multirow{3}{*}{$\begin{array}{c}\mathbf{P} \\
\text { Value }\end{array}$} \\
\hline & \multicolumn{2}{|c|}{ Successful } & \multicolumn{2}{|c|}{ Unsuccessful } & \\
\hline & $\mathbf{N}$ & $\%$ & $\mathbf{N}$ & $\%$ & \\
\hline $\mathrm{K} 1$ & 0 & 0 & 6 & 100 & $\mathrm{C}$ \\
\hline K4 & 0 & 0 & 6 & 100 & \\
\hline $\mathrm{K} 2$ & 3 & 50 & 3 & 50 & 0.55 \\
\hline K5 & 5 & 83.3 & 1 & 16.7 & \\
\hline K3 & 1 & 16.7 & 5 & 83.3 & 1.00 \\
\hline K6 & 2 & 33.3 & 4 & 66.7 & \\
\hline $\mathrm{K} 1$ & 0 & 0 & 6 & 100 & $0.02^{*}$ \\
\hline K5 & 5 & 83.3 & 1 & 16.7 & \\
\hline K1 & 0 & 0 & 6 & 100 & 0.45 \\
\hline K6 & 2 & 33.3 & 4 & 66.7 & \\
\hline $\mathrm{K} 2$ & 3 & 50 & 3 & 50 & 0.18 \\
\hline $\mathrm{K} 4$ & 0 & 0 & 6 & 100 & \\
\hline $\mathrm{K} 2$ & 3 & 50 & 3 & 50 & 1.00 \\
\hline K6 & 2 & 33.3 & 4 & 66.7 & \\
\hline K3 & 1 & 16.7 & 5 & 83.3 & 1.00 \\
\hline $\mathrm{K} 4$ & 0 & 0 & 6 & 100 & \\
\hline K3 & 1 & 16.7 & 5 & 83.3 & 0.08 \\
\hline K5 & 5 & 83.3 & 1 & 16.7 & \\
\hline
\end{tabular}

*C: constant value

Table 10. Drug side effects in each treatment group

\begin{tabular}{ccccc}
\hline & \multicolumn{3}{c}{ Side Effects } \\
\cline { 2 - 5 } Drug & $\begin{array}{c}\text { Dyspepsia } \\
\mathbf{N}(\%)\end{array}$ & $\begin{array}{c}\text { Dizziness } \\
\mathbf{N ~ ( \% )}\end{array}$ & $\begin{array}{c}\text { Dizziness and } \\
\text { Dyspepsia } \\
\mathbf{N}(\%)\end{array}$ & $\begin{array}{c}\text { No Symptoms } \\
\mathbf{N}(\%)\end{array}$ \\
\hline $\begin{array}{c}\text { Meloxicam 15 mg } \\
(\mathrm{K} 1+\mathrm{K} 4)\end{array}$ & $5(41.6 \%)$ & $0(0 \%)$ & $0(0 \%)$ & $7(58.3 \%)$ \\
$\begin{array}{c}\text { Meloxicam 15 mg \& } \\
\text { Tamsulosin 0,4 mg } \\
(\mathrm{K} 2+\mathrm{K} 5)\end{array}$ & $1(8.3 \%)$ & $2(16.6 \%)$ & $8(66.6 \%)$ & $1(8.3 \%)$ \\
$\begin{array}{c}\text { Tamsulosin 0,4 mg } \\
(\mathrm{K} 3+\mathrm{K} 6)\end{array}$ & $0(0 \%)$ & $4(33.3 \%)$ & $0(0 \%)$ & $8(66.6 \%)$ \\
\hline
\end{tabular}

Prostate inflammation causes the destruction of stromal and glandular prostate elements by pro-inflammatory cells. The process leads to an increase in PSA and prostate volume levels.
Increased prostate volume affects the static factor. Static factors (prostate enlargement), dynamic factor (smooth muscle contraction) and prostate inflammation will cause LUTS symptoms. In the 
decompensation phase, LUTS patients fall on acute urinary retention. Treatment of NSAIDs in LUTS is now considered to manage BPH. As it is known that in the prostate there was a large amount of COX-2 expression present in prostate smooth muscle cells. The use of a finasteride and rofecoxib combination had better results in reducing LUTS symptoms in BPH patients compared with single-treatment finasteride..$^{10,22}$

Alpha-blocker reduces bladder outlet resistance through smooth muscle relaxation of prostate tissue. This drug will facilitate the process of spontaneous micturition. Giving meloxicam $15 \mathrm{mg}$ as an anti-inflammatory reduces the inflammatory process of prostate tissue. Decrease of prostate tissue oedema and healing phase will be achieved. In the end, the prostate volume is reduced. This condition will decrease static factors of BPH pathogenesis and facilitate spontaneous voiding in urinary retention patients. ${ }^{4,10}$

This study found that the combination of meloxicam $15 \mathrm{mg}$ and tamsulosin $0.4 \mathrm{mg}$ was superior to meloxicam and tamsulosin $0.4 \mathrm{mg}$ alone. In this study, prostate and IPP volumes were not confounding variables against TWOC outcomes. This result is not similar with some reviews that reporting IPP and prostate volume are important factors influence the success of TWOC. ${ }^{3,4,10}$ Characteristics and size of the different samples are an acceptable reason for this differences. Duration of alpha-blocker administration and analysis of other comorbid factors that were not included in this study may also contribute to this differences. The highest success rate of TWOC was shown in the group treated with the combination of meloxicam $15 \mathrm{mg}$ and tamsulosin $0.4 \mathrm{mg}$ + catheter $20 \mathrm{Fr}$ compared with meloxicam $15 \mathrm{mg}+$ catheter 16 Fr and meloxicam $15 \mathrm{mg}$ catheter $20 \mathrm{Fr}$ (P value $<0.05$ ). This difference influenced by the size of catheter and combination of drugs (meloxicam drug $15 \mathrm{mg}$ and tamsulosin $0.4 \mathrm{mg}$ ). The more dilate of pars prostatic urethra can be found in a greater catheter diameter. Small catheter size (12 Fr to $16 \mathrm{Fr}$ ) is used for patients with urethral stricture, while larger sizes ( $20 \mathrm{Fr}$ to $24 \mathrm{Fr}$ ) are used for patients with prostate enlargement and for patients with gross hematuria. For cases of difficult urethral catheter insertion on $\mathrm{BPH}$, catheter size of $20 \mathrm{Fr}$ - $24 \mathrm{Fr}$ can be used. Catheter size $14 \mathrm{Fr}-16 \mathrm{Fr}$ can be used in the case of urethral stricture. ${ }^{23}$

Combination of meloxicam $15 \mathrm{mg}$ and tamsulosin can improve natural micturition ability, Qmax, and decrease PVR. This results also reported by another study, which found that the use of a combination of meloxicam and tamsulosin was better than single-tamsulosin therapy in LUTS symptoms in BPH. ${ }^{24}$ Combination therapy of meloxicam $15 \mathrm{mg}$ and doxazosin 4 mg per oral once daily for six weeks was better in increasing Qmax and decreasing prostate blood flow in BPH patients with LUTS. ${ }^{19}$ In a systematic review and meta-analysis of NSAIDs effects in LUTS BPH patient it was concluded that there were improvements in LUTS and urinary emissions as a result of NSAID administration. No serious adverse effects found. ${ }^{20}$ One clinical trial reported that the success rate of TWOC after tamsulosin $0.4 \mathrm{mg}$ compared to placebo about $63 \%$ and $37 \%$ respectively, and $33.8 \%$ and $24.3 \%$ respectively. ${ }^{11}$ Other study concluded that COX-2 inhibitors combined with alpha-blockers could improve the effectiveness of therapy for secondary LUTS due to BPH without significant effects. Thehigh success of TWOC in this study may be due to the synergistic effect between meloxicam and tamsulosin. The ability of meloxicam inhibiting COX-2 is thought to play an important role. Several studies have shown that high expression of COX-2 and prostaglandin may cause partial obstruction of the bladder outlet.25-27 The role of tamsulosin in reducing sympathetic tone in bladder outlets and prostate stroma also contributes to the success of TWOC. A study reported that tamsulosin was better than placebo with odds ratio $2.34 .^{12}$

This study also showed that a single treatment of $15 \mathrm{mg}$ meloxicam, has the lowest success rate compared to other groups. Therefore, in this study, it appears that acute urinary retention for the first episode of BPH patients is more likely to be dominated by sympathetic tone activity 
compared with inflammation.

The sssue of acute inflammation or chronic inflammation of the prostate as a presumed cause of acute urinary retention in BPH has been investigated. The study reported that the incidence of acute urinary retention was three times more common in chronic inflammatory prostate. ${ }^{15}$ Chronic inflammation of the prostate also tends to shorten the period of BPH patients with LUTS falling under acute urinary retention conditions. ${ }^{5}$ Therefore, further investigation is necessary to prove the dominance of sympathetic factors compared with inflammation in patients with $\mathrm{BPH}$ who have acute urinary retention of the first episode. The failure of meloxicam enhancing the success of TWOC is also affected by the paradoxical effect that NSAIDs themselves are risk factors for urinary retention. AUR risk 2.02 times higher in NSAID users than people who do not use it as therapy. Inhibitory effect of COX-2 enzyme in the bladder caused the decrease of prostaglandin synthesis and impaired of bladder contractions especially in AUR. ${ }^{28}$

This study shows that although the combination of meloxicam $15 \mathrm{mg}$ and tamsulosin $0.4 \mathrm{mg}$ has the best effect in reducing acute urinary retention, it is important to note that use of both treatment still has side effects. Side effects caused by the combination of these drugs more significant than other groups. Side effects of combination therapy such as dyspepsia and dizziness (66.6\%), dizziness $(16.6 \%)$ and dyspepsia (8.3\%) are still higher compare with tamsulosin alone (dizziness in 33.3\%) and also meloxicam alone(dyspepsia 41.6\%). In this study, it seems that numerous side effects were caused by the mechanism of each drug. Meloxicam is tolerable and relatively safe for atrisk groups such as geriatrics, renal insufficiency patients, and paediatrics. No cardiovascular severe or gastrointestinal problems can be found in treatment with meloxicam for 3 to 12 weeks..$^{29-31}$ Compared with diclofenac, piroxicam, ibuprofen and indomethacin groups; meloxicam has a lower incidence rate in gastrointestinal reactions, dyspepsia, gastritis, abdominal pain, and gastrointestinal bleeding. ${ }^{31}$ However, an adequate explanation for the side effects possibility should be given to the patient. Combination therapy should be noticed in patients who receive antihypertensive treatment and have a history of dyspepsia.

\section{CONCLUSION}

Combination of meloxicam $15 \mathrm{mg}$ and tamsulosin $0.4 \mathrm{mg}+20 \mathrm{Fr}$ catheter had a better effect in TWOC efficacy compared with the meloxicam $15 \mathrm{mg}$ + catheter 16 Fr group.

Further research is needed to prove the dominance between the role of sympathetic factors compared with inflammatory factors, including specifically the dominance of the role of chronic inflammation of prostate tissue compared with acute inflammation, in patients with BPH who have acute urinary retention of the first episode.

\section{CONFLICT OF INTEREST}

None of the authors have any conflict of interest.

\section{Acknowledgement}

Wahjoe Djatisoesanto (Department of Urology, Airlangga University/Dr. Sutomo Hospital, Surabaya) for the cooperation.

\section{REFERENCES}

1. Garraway WM, Lee RJ, Collins GN. High prevalence of benign prostatic hypertrophy in the community. Lancet. 1991;338(8765):469-71.

2. Briganti A, Capitanio U, Suardi N, Gallina A, Salonia A, Bianchi M, et al. Benign Prostatic Hyperplasia and Its Aetiologies. european urology supplement. 2009;8(13):86571. doi.org/10.1590/S1677-5538. IBJU.2015.0254

3. Roehrborn CG. Benign prostatic hyperplasia : etiology, pathophysiology, epidemiology, and natural history. In: Campbell-Walsh Urology. 10th ed. Philadelphia: Elsevier Saunders; 2012. p. 2570-610.

4. Mochtar C. Panduan penatalaksanaan klinis pembesaran prostat jinak (benign prostatic hyperplasia/BPH). ikatan ahli urologi indo- 
nesia; 2015.

5. Nickel JC, Roehrborn CG, Castro-Santamaria R, Freedland SJ, Moreira DM. Chronic Prostate Inflammation is Associated with Severity and Progression of Benign Prostatic Hyperplasia, Lower Urinary Tract Symptoms and Risk of Acute Urinary Retention. journal of urology. 2016;196(5):1493-8. doi. org/10.1016/j.juro.2017.01.035

6. Gandaglia G, Briganti A, Gontero P, Mondaini N, Novara G, Salonia A, et al. The role of chronic prostatic inflammation in the pathogenesis and progression of benign prostatic hyperplasia (BPH). BJU intenational. 2013;112(4):432-41. doi.org/10.1111/ bju. 12118

7. Jacobsen SJ, Jacobson DJ, Girman CJ, Roberts RO, Rhodes T, Guess $\mathrm{H}$ a, et al. Natural history of prostatism: risk factors for acute urinary retention. journal of urology. 1997;158(2):481-7.doi.org/10.1016/ S0022-5347(01)64508-7

8. Mcneill SA. The Role of Alpha-Blockers in the Management of Acute Urinary Retention Caused by Benign Prostatic Obstruction. european urology Journal.2004;45:325-32. doi.org/10.1016/j.eururo.2003.10.001

9. Schulman CC. Long-term aspects of medical treatment of BPH. european urology. 2001;40(SUPPL. 3):8-12. doi. org/10.1159/000049885

10. Fitzpatrick JM, Desgrandchamps F, Adjali K, Guerra LG, Hong SJ, El Khalid S, et al. Management of acute urinary retention: A worldwide survey of 6074 men with benign prostatic hyperplasia. BJU international. 2012;109(1):88-95. https://doi. org/10.1111/j.1464-410X.2011.10430.x

11. Bowden E, Hall S, Foley S, Rundle J. Tamsulosin in the treatment of urinary retention: a prospective, placebo-controlled trial. BJU international supplement. 2001;88(1):77. doi.org/10.1177/10 2F102490790801500104

12. Lucas MG, Stephenson TP, Nargund V. Tamsulosin in the management of patients in acute urinary retention from benign prostatic hyperplasia. BJU international. 2005;95(3):354-7. doi.org/10.1111/
j.1464-410X.2005.05299.x

13. Maldonado-Ávila M, Manzanilla-García HA, Sierra-Ramírez JA, Carrillo-Ruiz JD, González-Valle JC, Rosas-Nava E, et al. A comparative study on the use of tamsulosin versus alfuzosin in spontaneous micturition recovery after transurethral catheter removal in patients with benign prostatic growth. international urology and nephrology. 2014;46(4):687-90. doi.org/10.1007/ s11255-013-0515-y

14. Guang-Jun D, Feng-Bin G, Xun-Bo J. Alpha(1)-blockers in the management of acute urinary retention secondary to benign prostatic hyperplasia: a systematic review and meta-analysis. Irish journal of medical science. 2015;184(1):23-30. doi. org/10.1007/s11845-014-1094-3

15. Diseases BPHP, Tuncel A, Uzun B, Eruyar T, Karabulut E, Seckin S, et al.. Do Prostatic Infarction, Prostatic Inflammation and Prostate Morphology Play a Role in Acute Urinary Retention? european urology journal. 2005;48:277-84.doi.org/10.1016/j. eururo.2005.05.001

16. Kim BH, Kim C Il, Chang HS, Choe MS, Jung HR, Kim DY, et al. Cyclooxygenase-2 overexpression in chronic inflammation associated with benign prostatic hyperplasia: Is it related to apoptosis and angiogenesis of prostate cancer?. korean journal of urology. 2011;52(4):253-9. doi.org/10.4111/ kju.2011.52.4.253

17. Falahatkar S, Mokhtari G, Pourreza F, Asgari SA, Kamran AN. Celecoxib for Treatment of Nocturia Caused by Benign Prostatic Hyperplasia: A Prospective, Randomized, Double-Blind, Placebo-Controlled Study. urology. 2008;72(4):813-6. doi.org/10.1016/j. urology.2008.04.069

18. Ozdemir I, Bozkurt O, Demir 0, Aslan G, Esen AA. Combination Therapy With Doxazosin and Tenoxicam for the Management of Lower Urinary Tract Symptoms. Urology. 2009;74(2):431-5.doi.org/10.1016/j.urology.2009.01.088

19. Suarsana W, Hardjowijoto S, Wirjopranoto S, Budiono B. Doxazosin and Meloxicam Combination Therapy for BPH Treatment 
with LUTS. indonesian journal of urology. 2014;21(1).

20. Kahokehr A, Vather R, Nixon A, Hill AG. Non-steroidal anti-inflammatory drugs for lower urinary tract symptoms in benign prostatic hyperplasia: Systematic review and meta-analysis of randomized controlled trials. BJU intrnational 2013;111(2):304-11. doi.org/10.1111/ j.1464-410X.2012.11559.X

21. McNeill SA, Hargreave TB, Roehrborn CG. Alfuzosin $10 \mathrm{mg}$ once daily in the management of acute urinary retention: Results of a double-blind placebo-controlled study. Urology. 2005;65(1):83-9.doi. org/10.1016/j.urology.2004.07.042

22. Di Silverio F, Bosman C, Salvatori M, Albanesi L, Proietti Pannunzi L, Ciccariello M, et al. Combination therapy with rofecoxib and finasteride in the treatment of men with Lower Urinary Tract Symptoms (LUTS) and Benign Prostatic Hyperplasia (BPH). european urology. 2005;47(1):72-9. doi. org/10.1016/j.eururo.2004.08.024

23. Cancio LC, Sabanegh ES, Thompson IM. Managing the Foley catheter. american family physician. 1993;48(5):829-36. (PMID:8213413)

24. Gorgel SN, Sefik E, Kose O, Olgunelma V, Sahin E. The effect of combined therapy with tamsulosin hydrochloride and meloxicam in patients with benign prostatic hyperplasia symptoms and impact on nocturia and sleep quality. international brazilian journal of urology. 2013;39(5):65762. doi.org/10.1590/S1677-5538. IBJU.2013.05.07

25. Chughtai B, Lee R, Te A, Kaplan S. Role of inflammation in benign prostatic hyperplasia. reviews in urology. 2011;13(3):14750. PMID: 22110398

26. Masick JM, Levin RM, Hass MA. The effect of partial outlet obstruction on prostaglandin generation in the rabbit urinary bladder. Prostaglandins Other Lipid Mediator. 2001;66(3):211-9. doi.org/10.1016/ S0090-6980(01)00151-4

27. Park JM, Yang T, Arend LJ, Smart a M, Schnermann JB, Briggs JP. Cyclooxygen- ase-2 is expressed in bladder during fetal development and stimulated by outlet obstruction. American Journal of Physiology. 1997;273:538-44.doi.org/10.1152/ajprenal.1997.273.4.F538

28. Verhamme KMC, Dieleman JP, Van Wijk M a M, van der Lei J, Bosch JLHR, Stricker BHC, et al. Nonsteroidal anti-inflammatory drugs and increased risk of acute urinary retention. archive of internal medicine. 2005;165(13):1547-51. doi:10.1001/ archinte.165.13.1547

29. Reginster J. A Double-Blind, Three-Week Study to Compare the Efficacy and Safety of Meloxicam 7. $5 \mathrm{mg}$ and Meloxicam 15 mg in Patients with Rheumatoid Arthritis A Double-Blind, Three-Week Study to Compare the Efficacy and Safety of Meloxicam $7.5 \mathrm{mg}$ and Meloxicam $15 \mathrm{mg} .1996$.

30. Prouse PJ, Bevis PJ, Bluhmki E, Distel M. Evaluation of the safety, tolerability, and efficacy of meloxicam tablets in patients with osteoarthritis. clinical therapy. 1996;18(3):429-39. doi.org/10.1016/ S0149-2918(96)80023-3

31. Gates BJ, Nguyen TT, Setter SM, Davies NM. Meloxicam: a reappraisal of pharmacokinetics, efficacy and safety. Expert opinion on pharmacotherapy. 2005;6(12):211740. doi.org/10.1517/14656566.6.12.2117 